\title{
Pretense, Pride And Prejudice In Qualitative Leadership Research: An Appraisal And Two Examples From Europe
}

Jacqueline Fendt, (E-mail: j@jaygroup.ch), European School of Management, France Nada Endrissat, (E-mail: nada.endrissat@ unibas.ch), University of Basel, Switzerland

\begin{abstract}
In this paper we identify a number of prevailing epistemological inconsistencies in qualitative leadership research and suggest some emendations. We first analyze current research practices in the leadership field. We note that few qualitative studies are conducted and that many such so-called qualitative studies adhere wholly or partly to a positivist paradigm. We evoke possible rationales for this, i.e. we uncover mechanisms by which the positivist paradigm maintains its dominant position. Subsequently we propose an alternative research paradigm, social constructionism, and purport why this paradigm may be particularly suited to leadership research. By means of two practical personal research experiences we provide the reader with concrete examples of social constructionist leadership research and of what issues, barriers and satisfactions researchers might face during such a research journey. We conclude with some pragmatic ideas as to how scholars could be introduced to constructionist epistemologies and encouraged to apply interpretative research stances to leadership themes more often.
\end{abstract}

\section{INTRODUCTION}

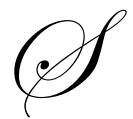

cholars have been exploring the nature of leadership in management and organizational studies for over a century. For many decades researchers from management and organizational fields, but also from a variety of other disciplines, have approached the subject statically, i.e. regarding types or traits of leaders (e.g. Bass, 1990; Burns, 1978; Weber, 1947) and/or the impact they achieve by their leadership (e.g. Carlyle, Goldberg, Brattin, \& Engel, 1993; Nietzsche, 1967). Later, leadership was increasingly studied dynamically, i.e. regarding the behavior of leaders vis-à-vis their followers (e.g. Bass, 1990; Machiavelli, 1610) and situatively, i.e. including the context in which leadership takes place (e.g. Herzberg, Mausmer, \& Snyderman, 1959; Maslow, 1954; Mayo, 192427). A large body of research is also concerned with the identification of models, tools, techniques and methods (e.g. Blake \& Mouton, 1964; Blanchard \& Johnson, 2000; Covey, 1990; Covey, Merrill, \& Merrill, 1994; Hersey \& Blanchard, 1969; Kanter, 1989; Lawler, 1987; Peters, 1992) to improve leadership efficiency and effectiveness and/or to seek answers about what 'good' leadership is and how to perform it. All these efforts have advanced our understanding of leadership - and yet substantial and essential knowledge gaps remain. So much so, that in the early 80s Cummings (1981) refers to leadership studies as a 'major disappointment'. Meindl et al (Meindl, Ehrlich, \& Dukerich, 1985) regret that "...after years of trying, we have been unable to generate an understanding of leadership". More recently, Clark sums up leadership research by admitting bluntly that "...no best measures to differentiate leaders from managers, or leaders from followers, or to identify those who will some day be leaders" could be identified (Clark \& Clark, 1994). Despite early awareness, great interest, important practical relevance and sustained scholarly effort, our knowledge of leadership has not advanced much: neither do we seem to improve our understanding on what leadership is, nor do the proposed models, theories and tools provide practitioners with useful suggestions on how to cope with leadership issues (Alvesson \& Sveningsson, 2003; Bryman, 2004; Fendt, 2005). 
We believe that part of the difficulty we continue to have in understanding leadership may stem from the fact that the field is still largely dominated by quantitative studies. Leadership issues are mostly approached from a positivist epistemological stance that views leadership, as a "...reality 'out there', as an 'object' separate from the scientist who observes [it]..." (Dachler, 1988, p. 262). Moreover, an overview of recent leadership studies (Bryman, 2004) yields that while scholars increasingly adopt - or claim to adopt - alternative approaches to the traditional large-scale, self-administered questionnaire, most of these studies still turn out to be essentially rooted in a positivist epistemology and thus quantitative in nature. That is, even when clearly qualitative methods and tools (such as ethnography, grounded theory or open interviews) are purported, they are often applied and/or analyzed following a distinctly positivist logic. We argue that this is partly due to the fact that the quantitative paradigm is commonly considered to be 'scientific' and 'good' - often exclusively so - while prejudice against other paradigms prevails. We highlight some mechanisms that we have found to inhibit researchers to work in more interpretive paradigms and we present an alternative research paradigm that encourages the adoption of a qualitative approach. To substantiate our argumentation we share with the reader two recent leadership projects based on a distinctly qualitative epistemology. We describe the research methods applied and the analyses performed and we evoke some critical research issues, such as quality criteria and representativeness. In the final section of the paper we summarize the most common questions concerning qualitative leadership research ${ }^{\mathrm{i}}$ and provide our suggestions on how to deal with them. We close by making a number of pragmatic recommendations on how some of the identified barriers to work in a more interpretive paradigm could be overcome and how qualitative research could become more established in the broader scientific community.

Let us now start by looking at today's practice of leadership research and its inherent problems of pretense, pride, and prejudice.

\section{LEADERSHIP RESEARCH TODAY}

An overview of the current application of research methods in management studies, specifically in leadership research (e.g. Bryman, 2004) yields that most empirical research in the leadership field today is overtly or vicariously quantitative in nature. Three examples:

- Interview forms: The self-administered large-scale questionnaire is still the instrument of choice (Bryman, 2004). Many studies claim to part from a interpretivist theoretical perspective but subsequently analyze their (so-called) qualitative interviews following a realist, quantitative approach (King, 2004).

- Ethnography: Van Maanen (1988), a profiled interpretive scholar, offers researchers a seminal body of research on ethnographic inquiry, a methodology which explicitly "... seeks to uncover meanings and perceptions on the part of the people participating in the research..." (Crotty, 1998, p. 7). Van Maanen finds it necessary to propose a choice of three ethnographic narrative forms, namely the realist, the impressionist and the confessional tale, of which the realist form is clearly epistemologically objectivist.

- $\quad$ Grounded Theory Method (GTM): In the same vein, another affirmed interpretive research method, namely GTM sends mixed messages to researchers. On the one hand, the method is introduced by its founders as a creative and heuristic way of dealing with qualitative data and they promise to: "...keep the discussion openminded, to stimulate rather than thinking about the topic" (Glaser \& Strauss, 1967, pp. 8-9) and, later, call the method "both a science and an art", explaining that the proposed "procedures were designed not to be followed dogmatically but rather to be used creatively and flexibly by researchers as they deem appropriate" (Strauss \& Corbin, 1998, p. 14). On the other hand, the same proponents impose on researchers a draconian regime of objectification, coding and fracturing on the rich data gathered through observation and narrative interviews, with the purpose to "...free the researcher from description..." (Strauss, 1987, p. 55).

These non-exhaustive examples suggests that not only in the everyday application, but even in the original teaching material that is provided by the creators and followers of certain interpretive methodologies, the adoption of a qualitative research approach does not necessarily imply an alternative epistemological position. In line with Crotty (1998) we grant that quantification is not necessarily ruled out in non-positivist research, nor is all objectivist research necessarily devoid of qualitative contributions, without this being a problem. But, with Crotty still, we see it as problematic when the underlying theoretical perspective, the paradigm on which the research endeavor rests, is at once objectivist and subjectivist: 
"On the face of it, to say that there is objective meaning and, in the same breath, to say that there is no objective meaning certainly does appear contradictory. To be sure (...) we are invited today to embrace 'fuzzy logic' rather than the logic we have known in the past with its principle of contradiction. (...) We will need to be consistently objectivist or consistently constructionist" (1998, p. 15, emphasis by the authors).

In line with Kirk and Miller (1986, p. 11) and with Silverman (2001, p. 219) we argue that issues of reliability and validity are important as the objectivity and credibility of social research is at stake. And even though as we produce descriptions of a social world, such descriptions are bound to a particular perspective and context and therefore representations of reality rather than reproductions, such representations can be described in such a way as to permit some kind of empirical verification (see e.g. Peräkylä, 2004 for an excellent account of methods of empirical verification in research based on naturally occurring social interaction). Our criticism thus does not address the claim for rigor in interpretivism (as in all serious research for that matter), but addresses research that may bear in it certain contradictions of positivism and interpretivism at the same time, i. e. certain epistemological inconsistencies. We provide some examples and argue our case under the terms 'pretense, pride and prejudice':

- $\quad$ 'pretense' refers to the fact that although many research projects claim (pretend) to follow a qualitative (interpretivist) theoretical stance, the methods that are chosen and the way in which they are utilized is often in a positivist way, i.e. the choice and application of research tools and methods, as well as the data analysis processes, often follow an objectivist logic (usually Likert scales and linear regression)

- $\quad$ 'pride' refers to the fact that some pioneering qualitative methods of the 60s (e.g. GTM and ethnographic inquiry) have still not entirely emancipated themselves from their époque vocabulary and from certain positivist, objectivizing tools. We argue that they risk, by that, to undermine the very constructionist potential they (wish to) bring to the research arena

- $\quad$ 'prejudice' refers to the tenaciously prevailing notion that interpretive research is 'not scientific' and that only the quantitative paradigm is 'scientific' and 'good'.

Again, our case is not meant to be fundamentalist and in the debate on whether qualitative and quantitative methods can be and should be conjointly applied in one and the same research project, we do not à priori take an absolutist stance. There may be instances where an antecedent quantitative research loop may help to better define a research area which is then researched interpretively. We simply argue that researchers should 'walk the talk', i. e. clearly announce their epistemology and describe their approach and then pursue it, unflinchingly. Mixed messages, as outlined above, can be problematic because they confirm the prejudice that qualitative research is 'not serious science', reinforce the (conscious or unconscious) pretense of doing qualitative research when in fact it is not and thus prevent scholars from using such methods to their full potential. It may also simply confuse young scholars on the lookout for optimal research methods and deter them from trying an interpretative method.

Perhaps by lacking self-confidence and wanting to go beyond interpretation of narratives to offer more than sound ideography (the very legitimacy of hermeneutics, see Gadamer, 1972) scholars risk to subject the narrative to an "unhermeneutical approach to hermeneutics" (Sherman, 1988, p. 395) as data is 'neutralized' or 'objectivized' in 'realist' forms of interviews or ethnography, or pushed through a set of fractioning and objectifying procedures that are supposed to transform it into some kind of objective theory. These neutralizing procedures seem to be an attempt to duplicate the neutral controls in natural sciences in the hope that they would yield the same objectivity. But procedural objectivity does not yield ontological objectivity because "consensus achieved through procedural objectivity provides no purchase on reality. It merely demonstrates that people can agree" (Eisner, 1993, p. 53). It is true that such claims of researcher disinterestedness and objectivity are occasionally criticized and some profiled scholars encourage researchers to be: "... active agents and not "passive recipients of larger social forces"” (Charmaz, 2006). Fish (1994) calls it "zany" to pretend that anyone can "in some way step back from, rise above, get to the side of your beliefs and convictions", i.e. be - or want to be for that matter - neutral. And for Charmaz and Mitchell (1996) the "myth of silent authorship is false but reassuring" and, as we may add, "reassuring but false". Some scholars do go as far as developing more solidly qualitative variants of extant research methods. Charmaz, for example, proposes a new form of Grounded Theory Method, which she labels "constructivist GTM" (2000; , 2006). This can be seen as a first attempt in overcoming the prevalent pride in the GTM field. But voices like Charmaz' are not yet dominant in the management research arena and the mixed messages still prevent young leadership researchers from applying interpretivist re- 
search stances.

\section{WHY IS THE POSITIVIST PARADIGM SO PERSISTENT?}

To overcome the stated problems and to promote the adoption of interpretative paradigms one should probably begin by seeking to understand the mechanisms by which the positivist logic may maintain its dominant position. "This way the limits that previously maintained the status quo can be (re-)constructed" (Dachler \& Hosking, 1995, p. 9). To achieve this, we refer to the sociology of knowledge according to Berger and Luckmann (1966). In their seminal work, the two authors delineate the social construction of reality from a 'sociology of knowledge' perspective. They argue that externalization, objectivation and internalization are the three dialectic processes of social reality. "Potentially shared ways of thinking about the world ('knowledge') become externalized when they take the form of social practices or artefacts. These then become 'objects' (objectivation) for a social group, and acquire a sense of pregivenness. They then become part of the thinking of individual members of the social group (internalization), and of new members as they are born into it" (Burr, 2003, p. 202). A further aspect is the legitimation, i.e. the way in which the social world is explained and justified (Berger \& Luckmann, 1966). By these processes the socially constructed reality becomes a seemingly 'objective' respectively 'hard' reality to the individual and the collectivity. In such subjectivist logic, this 'reality' is, however, like all understanding, scientific or non-scientific alike, nothing but a human product. What is considered to be 'good science' is a social construction that has received the status of an objectivity, the underlying logic of which is no longer questioned since we take the status for granted. Some mechanism that help to maintain the positivistic paradigm in its dominant position and that render acceptance of interpretive research difficult could thus include availability and publishing issues It seems necessary to make the pervading assumptions explicit and a topic of discussion: "This way the limits that previously maintained the status quo can be (re-)constructed" (Dachler \& Hosking, 1995, p. 9).

In addition to the traditional, philosophical in-fights about what is 'true science' and who has the key to the holy grail of meaning making, Cassell and Symon (2004) identify some more pragmatic, practical problems. For research to become part of the universal body of knowledge it needs to get published. And, more pragmatically, for researchers to progress in their professional career, their work needs to get published. Only if and when a critical mass of exciting and meaningful qualitative research is available, can scholars who wish to make a lasting contribution to the body of science make informed epistemological and methodical choices. So, availability and publishing mechanisms may also play a role in the tenacious conservation of the reproduction of positivist dominance: The mechanisms therefore include:

- the problem of getting qualitative research past epistemological gatekeepers (journal editors and reviewers, conference committees)

- $\quad$ the existing pressure to justify research methods according to inappropriate (normative) criteria

- $\quad$ the fact that researchers are given little exposure to alternatives. For example, PhD students are most often trained in positivist research methods

To this list of mechanisms by Cassell and Symon (2004, p. 3), we would like to add:

- $\quad$ the mixed epistemological messages between positivist and interpretivist that reign in the qualitative research methods literature and practice (see our arguments above).

In summary, we argue that through the described mechanisms, i.e. through processes of ongoing reproduction, certain specific assumptions - in this case the assumption that research must be quantitatively measurable in order to be good - receive the status of objectivity. These assumptions are difficult to change because of their internalization. They are also hard to upturn because established social constructions are tenacious, since they are "presumed to serve someone's interests, usually those of the powerful" (Patton, 2002, p. 101). 


\section{AN ALTERNATIVE PARADIGM: SOCIAL CONSTRUCTIONISM}

So far, the paper has outlined current research practices in the leadership field and tried to understand why the positivist paradigm is so solid. It is no secret to the reader by now that the authors regret this solidity of the positivist paradigm, as far as leadership research is concerned. For many types of leadership research questions, the usefulness of the dominant practice in which a standardized questionnaire is mailed to potential respondents who are asked to fill it out by indicating their response on Likert scales is questionable to us. The standardized answer categories produced are likely to reproduce commonly agreed upon leadership understandings (e.g. Alvesson \& Sveningsson, 2003) and thus, at best, reveal nothing 'new' and, at worst, cement possibly comforting but probably false commonplaces on leadership dos and don'ts. Such statistical results are also quite distant from real life experiences (Silverman, 2004) and issues leaders face every day and cannot possibly do credit to the ever-changing and highly relevant leadership context in which the reported behaviors and actions take place. So much so, that often the quantitative approach reveals little about how leadership is actually seen and practiced.

As a consequence, we argue for an alternative epistemological viewpoint, namely that of social constructionism. The focus of leadership research under this paradigm is on the "what", "why" and "how" of the relationship between humans and society. A theoretical and/or practical point of view is therefore recommended that advocates the study of direct experience taken at face value; one which sees behavior as determined by the phenomena of experience rather than by external, objective reality (Cohen \& Manion, 1989). A constructionist ${ }^{\mathrm{ii}}$ stance (Crotty, 1998; Gergen, 1994; Ryle, 1949), in which, according to Clarkson, "people cannot be understood outside of the context of their ongoing relationships with other people or separate from their interconnectedness with the world" (Clarkson, 1989), lends itself well to such exercises. Easterby-Smith et al recommend the use of constructionism, rather than positivism, in research where:

- $\quad$ the observer is part of what is being observed (and not independent)

- $\quad$ human interests are of relevance

- $\quad$ explanations aim to increase the general understanding of the situation (rather than to demonstrate causality)

- $\quad$ the research progresses not through hypotheses and deductions but by gathering rich data from which ideas are sought

- units of analysis are not reduced to simplest terms but may include the complexity of the 'whole' situation

- generalization is sought through theoretical abstraction, and not statistical probability (Easterby-Smith, Thorpe, \& Lowe, 2002, p. 30).

Contrary to the entitative perspective, which puts the focus on the individual, the constructionist perspective focuses on relationships (Burr, 2003) ${ }^{\text {iii. }}$. Whatever we perceive as real ("real-ize") exists through communication and interaction between humans. This is especially interesting in relation to humans in leadership situations, where leaders and followers form an entity, in a particular context at a particular moment and need to develop - through interaction a common understanding, shared values, a discourse of their own and entity-inherent standards best suited to achieve the entrepreneurial objective at hand. In this sense, these entities of leader, led and context create their realities: local ontologies are shaped ${ }^{\mathrm{iv}}$. Constructionism takes a critical stance towards taken for granted knowledge that is often mistaken for being the 'truth'. According to Watzlawick (Watzlawick, 1995, 1997; Watzlawick \& Kreuzer, 2000), the recognition of absolute truth is not possible since such absolute truth does not exist. However, academic work can still be performed because the notion of absolute truth is not decisive. In line with the above purported arguments of Easterby-Smith et al., a social constructionist approach (e.g. Burr, 2003; Gergen, 1994) is appropriate when behavioral phenomena are the focus of interest, i.e. when people, groups, systems and their interrelation in a variety of contexts are observed and analyzed. The focus of such leadership research lies in the relational perspective of social systems and not in the individual. This approach is in contrast with some traditional and populist, personalist approaches, which attribute management success or failure and similar social phenomena primarily to the individual (Denzin \& Lincoln, 2003; Rüegg-Stürm \& Gritsch, 2001). Recent systems theory (Luhmann, 1994) builds on constructionism, second-order cybernetics ${ }^{\mathrm{v}}$ and the theory of autopoietic systems ${ }^{\mathrm{vi}}$. It understands systems as structured flows of communication, i.e. as chains of events (Peterson, 1988). The organization as a system of events has an order, which manifests itself by routines and material and immaterial structures (discourses). Relevant from a systems-theoretical perspective is how such a system is observed, how observation is performed within it, how reality and knowledge are 
created. Observation is interpretation and, by that, construction of reality. Through the lens of existing material and immaterial structures, as well as in the respective context, the observed is interpreted. Social constructionism implies that social phenomena - like, for example, leadership - are socially constructed in and through peoples' interaction, rather than representing objective facts that are 'naturally given'. Therefore, the optimal focus is not on examining leadership traits and attributes but on how people interact in situations typified as 'leadership' and what kind of relationships and leadership realities they construct and, possibly, to what effect (Dachler \& Hosking, 1995).

To illustrate what such research on leadership could look like, we share with the reader two recent research projects that were carried out under a social constructionist paradigm. The first case study is concerned with the meaning of leadership in the German speaking-part of Switzerland (Endrissat, Müller \& Meissner, 2005). The second case study observes how CEOs cope with multiple demands in post-merger situations (Fendt, 2005). Each case study outlines the research process and addresses specific research-relevant issues such as validity or neutrality.

\section{CASE 1: LEADERSHIP RESEARCH IN SWITZERLAND}

Viewing leadership from a social constructionist perspective implies that no single objective and true definition of leadership exists. Instead, the leadership understanding differs depending upon the specific societal, cultural, and historical context. In this first case, we further assume that the mutually created leadership reality is influenced by the individuals' implicit leadership understanding as well as self-conceptions that are contingent upon the individuals' experiences and socialization processes. We argue that the implicit understanding of leadership provides the respective actor with a basic framework of appropriate and expected leader and follower behavior: it defines, gives meaning to, and directs the interaction process. The self-conceptions and implicit leadership understandings act as 'hidden agendas' and instruct the individual actor 'from backstage' with respect to, for example, what it means to be leading or being led, how it should be performed, and how 'good' leadership as well as 'leadership success' are defined (see also Lord \& Maher, 1991).

In order to understand what leadership means to practitioners, a research method is required that provides access to the individuals' self-conceptions and implicit leadership theories. The research instrument needs to capture how leadership is thought, made, and experienced.

\section{The Research Method: Narrative Interviews}

To get access to the self-images and implicit leadership theories we conducted narrative interviews (e.g. Czarniawska, 2004). The method is claimed to yield stories and experiences that reveal the understanding and meaning of the narrator's every-day-life reality. By emphasizing and repeating specific aspects and by interpreting certain events, the narrator's perspective, his or her frames of reference and implicit understanding concerning leadership become available. We assume that even though the narrated stories refer to past experiences, they disclose the narrator's current understanding of leadership because the descriptions are influenced by the narrator's currently active frames. Czarniawska (2004, p. 49) adds that what people present in narrative interviews "is but the results of their perception, their interpretation of the world, which is of extreme value to the researcher because one may assume that it is the same perception that informs their actions". While the interviewee narrates, the interviewer takes on an 'active listener' position and closely follows what is being said. In order to get close to the subjective understanding the respective interviewee holds, possible questions should always be open and not suggest any categories or concepts.

We started each interview by inviting the interviewee to tell us about their first experience with leadership. The question we applied was as follows:

'Mr.Ms. ..., we know you are currently in a management position. We would like to ask you to think back and tell us about your first experience with leadership. What happened, what did it mean to you, how did you experience it?'

All interviews were conducted in a comfortable surrounding, usually the interviewee's office or home. The interviews varied between $1.5-2$ hours, all were recorded and subsequently transcribed. 


\section{Sample}

It is important to stress that we did not aim at representativeness but instead strove for generalizability in the sense of revealing the 'typical'. To achieve this, our sampling strategy was one of maximum variation (heterogeneity). Patton (2002, p. 234) puts forward that "this strategy of purposeful sampling aims at capturing and describing the central themes that cut across a great deal of variation". The logic is that "any common patterns that emerge from great variation are of particular interest and value in capturing the core experiences and central, shared dimensions of a setting or phenomenon"(Patton, 2002, p. 235). In other words, if we grasp as much variety as possible in our sample but are nevertheless able to identify commonalities among all these individual variations, we can conclude that we have found something that is central to our research topic. As a consequence, we have conducted twenty-six interviews with leaders who represent male as well as female managers, different hierarchical levels, and different age categories. They work in various organizational settings and hence provided a great variety of different perspectives.

\section{Data Analysis}

The overall aim of the analysis was to understand the meaning of leadership from the narrator's point of view (Bryman, 1984, p. 77; Bryman, Bresnen, Beardsworth, \& Keil, 1988, p. 61; similarly Smircich, 1983, p. 166). To reduce the influence of our own frames of reference and to increase the validity of the interpretation, the data analysis involved several steps.

In a first step, we interpreted the interview scripts individually. We were trying to see through the eyes of the interviewees and asked ourselves: 'What topic is the narrator addressing in this episode?' 'What does the narrator want to tell me here?' 'What is his or her message?' The aim of the analysis was neither to summarize what the narrator was saying nor to categorize and count the statements. We also abstained from focusing on the personality of the narrator, i.e. we did not 'psychologize' by referring to traits, causes or dynamics of the person. This resulted in a list of approximately 6 to 12 topics. A topic is an issue that is repeatedly (at least three times) addressed throughout the interview and can therefore be seen as characterizing one of the cornerstones of the interviewee's leadership understanding. In a second step we met in our research group and compared our individual interpretations. The aim was to control as much as possible for the intrusion of our own concepts into the interpretation of the empirical material. This second step can be seen as a 'communicative validation', i.e. the evaluation of the interpretation in a dialogue, as suggested by Kvale (1995). After having identified the topics of one interview, the research group tried to get the "whole picture', that is, we tried to relate the different topics within one interview to each other. To support this process we applied the 'cognitive mapping' technique (McDonald, Daniels, \& Harris, 2004). A cognitive map is generally a pictorial representation of the data. Since our data deals with the understanding of leadership we call the maps 'leadership landscapes'. A further step to enhance the interpretation's validity was to obtain the interviewee's reaction to our reconstruction of his or her leadership understanding. For this, we sent the transcribed interview together with the interpretation of topics back and asked for their opinion concerning the plausibility of the interpretation. The interview analysis further involved the aggregation of the individual leadership understandings to a collective one. To achieve this, we screened the material for 'commonalities' that were evident among the variations. That is, among the twentysix interpretations we looked for similarities and recurring topics. At the end of the data analysis we had (re)constructed twenty-six individual leadership understandings as well as one 'overall' Swiss leadership understanding (which was validated in a final workshop with the interviewees).

The results reflect the socially constructed leadership phenomenon in its cultural and societal context. They help to identify prominent dilemmas and topics that managers are dealing with every day. Yet, our results do not depict an 'ideal' form of leadership nor do they imply that all topics are equally important to all managers. Instead, they help to mirror the implicit leadership understanding that the practitioners hold and that determine to a considerable part their interaction with others. By making the implicit explicit the managers can reflect on their leadership realities and the costs and benefits that are associated with it. They might be able to obtain a new perspective on the possibilities of relating and exercising 'leadership'. 


\section{Some Objections}

Different audiences with whom we share our research and its results have different reactions. When presenting it at 'mainstream' conferences or to management scholars that were trained in the 'traditional research way', a number of objections are made. For the purpose of this paper we have chosen to comment on the three objections that we encounter most often. We label them 1.'but your results are not representative', 2.'what about objectivity?' and 3. 'how can you ensure that your results are valid?'. Our general conviction is that issues such as representativeness or validity of results are, to speak with Dachler, only problematic "in the context of the realist epistemology. Within the ontology of social constructionism, taken seriously in all its implications, these problems become mute" (1997, p. 718). As was noted earlier, the aim of social constructionism research is not to identify objective facts that can be replicated in any context. Nor does social constructionism claim to uncover 'the truth'. The concepts of objectivity, reliability, and validity are therefore inappropriate for evaluating the quality of social constructionist's research design and results (e.g. Burr, 2003; Madill, Jordan \& Shirley, 2000). Nevertheless, it seems important to address these issues here since the objections are the result of the unfamiliarity with the interpretive paradigm and addressing them here will hopefully foster the understanding of this research approach.

\section{But your results are not representative!}

Our sample size is - compared with statistical research - rather small. When confronted with this objection it is important to explain that our research does not aim at representativeness or statistical, empirical generalizability in the traditional sense but instead strives for theoretical generalizability, in the sense of revealing the 'typical'. To achieve this, our sampling strategy is one of maximum variation (heterogeneity). Patton (2002, p. 234) puts forward that "this strategy of purposeful sampling aims at capturing and describing the central themes that cut across a great deal of variation". The logic is that "any common patterns that emerge from great variation are of particular interest and value in capturing the core experiences and central, shared dimensions of a setting or phenomenon" (2002, p. 235). In other words, if we grasp as much variety as possible in our sample but are nevertheless able to identify commonalities among all these individual variations, we can conclude that we have found something that is central to our research topic. In our case, we have conducted twenty-six interviews with leaders who represent male as well as female managers, different hierarchical levels, and different age categories. They work in various organizational settings and hence provide a great variety of different perspectives. Because we were able to find recurring and common topics among all the variation, we assume that our results say something about leadership in Switzerland that may have relevance for a greater audience than just our interview partners.

\section{What about objectivity?}

As mentioned above, we do not believe that research results can be empirically 'objective' since they are necessarily a (re-)construction of how people experience their social reality. As a consequence, we believe that attention to transparency (i.e. how were the data collected and how were they analyzed) and traceability (i.e. the interpretation needs to be plausible and traceable) are more significant for interpretive research. Similarly, Burr (2003), Lincoln (Lincoln \& Guba, 1985, 2003), Madill et al. (2000) and Miles and Huberman (1994) have suggested alternative criteria to assess the scientific quality of qualitative research.

\section{How can you ensure that your results are valid?}

What we have said so far also applies to the quality criteria of validity: Because we are working under the interpretive paradigm, validity has a different meaning. Here, the results are valid when the data are analyzed from the narrator's point of view (see above). This implies that we try to reduce the influence of our own concepts, schemata and implicit theories when interpreting the interview. We address this challenge by being aware of the possibility that our own topics and concerns can 'intrude' the material, and by openly discussing and disclosing such dangers of intrusion. Also, we compare our interpretations with the ones of other group members ('communicative validation', see Kvale, 1995) and, finally, ask the respondent to comment on our interpretation. 
In summary, there are legitimate arguments in favor of objections people might have against the use of qualitative research. But also against: to work qualitatively does not imply that there are no quality standards in qualitative research. To work from a constructivist epistemology does not imply that 'anything goes'. Qualitative research is very demanding and before choosing it one should be aware of this and be convinced of the benefits. Otherwise, the challenges and objections encountered by traditionalist scholars could lead to a relapse into a positivistic paradigm.

\section{CASE 2: CEOS IN M\&A}

The second study used here as example (Fendt, 2005) observes how Chief Executives (CEOs) cope with the multiple and often conflicting demands placed on them in a post-merger context. Such a study is complex and stochastic because it concerns real life business situations which involve a large number of interrelated variables, many of which random. Also, it concern events that are relatively unique and irreproducible and that take place in a fastchanging context (Remenyi, Williams, Money, \& Swartz, 1998).

The research included two major sources of field evidence. The researcher was herself a rare female CEO of an important Swiss company and later of Swiss Expo, a fair cum exhibition that every generation mobilizes the entire society to reflect upon itself and look into the future. In these capacities she became a mediated personality and had daily contacts with the business elite of her region. She kept a detailed professional diary of these contacts and in a first research loop distilled this data into seven ethnographic impressionist tales illustrating various facets of the mergers and acquisition game and its principal actors. This way she could use the rich data collected over many years of active presence in the field on the rites, practices, power relationships, kinship patterns and, simply, ways of life of CEOs. Based on this ethnographic excursion she wanted to pursue the research journey by interviewing a number of the above actors more concretely. For this second research loop, a case study approach, combined with Grounded Theory Method (GTM) was chosen for the following reasons:

- $\quad$ "A case study is an empirical enquiry that investigates a contemporary phenomenon within its real-life context; when the boundaries between phenomenon and context are not clearly evident; and in which multiple sources of evidence are used (Yin, 1984)". Eisenhardt (1989), too, recommends the case study method for explorative, descriptive and explanatory questions, especially for new subject areas where theory is scarce and where new content and a fresh perspective are sought. This described exactly the status and object of the inquiry at hand.

- GTM's central objective is stated to be theory building, rather than theory testing. Given the lack of a theoretical body on executive leadership and learning in transitional organizations, an inductive approach by which theory would emerge from the experiential accounts of the executives themselves seemed appropriate

- GTM gave clear guidelines both for the conduct of the research as well as for interpretation of evidence, which offered some assurance to the researcher.

- In this interpretivist method of inquiry discourses, gestures and actions are all stated to be considered primary to the experience. This experiential research included observations of behavior. This was important as it was expected that executives would not necessarily articulate all their experiences, thoughts and feelings. In consequence, GTM, which promised to allow for a wider range of evidence, was preferred over research methods that rely solely on descriptive accounts (e.g. phenomenology).

- $\quad$ The strengths of this approach are said to lie in its depth of enquiry and its unimpaired interplay between theory and empiry. It permits an understanding of the dynamics of particular situations and is claimed to lead, by creative reframing, to new theoretical approaches that, due to their vicinity to empiry, represent as a rule empirically valid hypotheses or theories (Eisenhardt, 1989). Weaknesses include the difficulty to generalize results (McClintock, Brannon, \& Maynard-Moody, 1979).

To avoid some of the described issues, a longitudinal, exploratory, multiple case study design with triangulation was chosen and the criteria of reliability and validity were observed in a systematic, documented approach throughout the preparatory phase, evidence collection, evidence analysis and evaluation. Longitudinal, because the temporality permits to observe phenomena throughout a variety of contextual situations and permits a more solid confirmation of their existence and a clearer understanding of their nature; exploratory, because situations are explored in which the studied phenomena have "...no clear, single set of outcomes" (Yin, 1982) and multiple-case because it adds 
confidence to findings if a replication logic is followed (Miles \& Huberman, 1994). Both literal replication logic (similar results to previous cases) and theoretical replication (contrasting results but for predictable reasons) were tested. Reliability was addressed by a systematic documentation of the research process and by a longitudinal approach over a period of over two years. Validity was addressed as construct validity by communicative validation in the shape of respondent checking and member checking, and chains of proof. The 'proposals of reality', which were gained from the analysis were mirrored back to the interviewees and their feedbacks taken into account and incorporated into the results. Furthermore, all analysis and interpretation data was given to a fellow doctoral student to ensure consistency of interpretation and reduce subjectivity. Total coherence between the viewpoints of the interviewees and of the researcher was not sought, but the differences in interpretation were made visible to the reader. Internal validity was addressed with suitable analytical instruments and careful documentation of the process whilst external validity was sought with replication (several case studies) and triangulation with the ethnographic observation.

Ten post-merger cases were chosen by theoretical sampling and described in terms of their nature, location, M\&A motives, post-merger status and the fieldwork conducted. The main research focus was on the Chief Executive Officer (CEO). Each executive was interviewed twice, with a time interval of no less than 6 months between the two formal, narrative interviews. To reduce subjectivity, one further member of CEO's management team was also interviewed, also twice with a time interval of no less than six months. The two-interview approach gave the study a longitudinal dimension, permitted to verify emerging concepts against possible changes in behavior over time due to learning, context or mood and allowed the researcher to 'break the ice' and get very candid self-assessments from the subjects, including a glimpse into highly personal matters. This process resulted in a considerable mountain of data of 40 very long, narrative in-depth interviews with 20 top executives from 10 different companies, as well as detailed notes from 117 formal meetings and several hundred informal encounters with leading executives of the ten case companies, plus hundreds of notes from observational and documentary evidence, the author having gained good access to confidential corporate material. This data was then coded, iteratively abstracted, any theoretical significance explored and contrasted with available theoretical frameworks, and subsequently developed into concepts and higher order categories and their respective characteristics and dimensions. These findings were in turn related to other factors that had been identified as being important and memoed throughout the process, such as a number of socio-cultural conditions, personal background conditions and current contextual conditions. Finally, the concepts and categories were incorporated into a theoretical framework.

What seemed like a fairly structured and systematic research approach posed considerable problems right from the start and throughout the research process. The first problem had to do with the GTM recommendation to bring no extant literature to the project before the field work so as not to start the field research with preconceived ideas and bias, but only in a second step, as additional data, once the primary theoretical framework had emerged from rigorous data collection and analysis (Glaser, 1978, 1992). For one, this was simply impossible since it was the extensive search for answers both in practice and theory that had given rise to the research intent in the first place! Also, the call for a blank slate irritated the researcher, since, as described above, she had chosen this method for its interpretivist capacity and, surely interpretation is likely to benefit from a large theoretical and practical baggage of the interpreter? Fortunately, a more detailed study of qualitative methods had yielded that there was in fact not one GTM, but that several mutants of the method had solidly implanted themselves in the qualitative research arena. Well beyond the original and much-covered dispute of the two founders Glaser and Strauss, over theory "emergence vs. forcing" (Locke, 2001), methodological variations on the theme of Grounded Theory had been developed and imposed themselves. So much so, that many grounded theory bibles did in fact recommend to begin the research with abundant prior knowledge, including a literature overview, which, to avoid bias, is to be performed very widely and eclectically (Charmaz, 2006; Easterby-Smith, Thorpe, \& Lowe, 2002; Goulding, 2002; Locke, 2001; Strauss \& Corbin, 1998). This approach was chosen here and resulted in a wide theoretical assessment condensed into some 150 tightly written pages on the state-of-the-art, drawing from eight major fields of management theory and a dozen subfields. While it is unclear if and how much this wide literature search did directly or indirectly serve the study but it certainly provided the researcher with a solid eclectic knowledge base, a kind of 'studium generale', from which to draw a number of interdisciplinary learnings when ping-ponging iteratively between data and literature in the later stages of the project.

A second irritation was caused by the severe and repeated imposition (in the literature) of neutrality, impartiality and dispassion on the researcher. How could the researcher possibly be dispassionate, when it was passion that 
had brought her to inquire into the subject in the first place? And how could she be neutral - she had just spent over ten years living with the tribe of CEOs and observing them? And, if by some extraordinary effort such a state of neutrality were achieved, what good would it be? Would it not come at the price of abjuring to the rich experience the researcher could bring to the table? Again, the researcher wondered if she had indeed chosen a qualitative method, or if GTM was, after all a quantitative wolf in a qualitative sheepskin. This problem was handled in that, rather than avoid choices, the researcher decided to disclose them and thoroughly document the stance from which they were made. After all, to live is to choose: the sheer statement of the nature of the problem under investigation is a choice, and so are the cases, the methods, the respondents, the interview questions and so on. To write anything is inevitably to include or exclude, i.e. to be partial no matter how much one wishes to address or close off possibilities. Gadamer rejects the idea of pure induction. For him, interpretation is to a certain extent a deduction from what Glaser and Strauss call, with some disdain, 'a priori assumptions' $(1967$, p. 6). Gadamer suggests taking the scholar seriously and capable of intellectual probity: "after all, the researcher has made a decision that the research project is worth his or her while. Meaning exists... at the beginning of any... research as well as at the end: as the choice of the theme to be investigated, the awakening of the desire to investigate, as the gaining of the new problematique" (Gadamer, 1972, p. 97).

What's more, it seemed that the credibility of social inquiry itself was challenged by this demand of selfeffacement. Is social constructionist inquiry not about the interpretation of meanings that we read into the encounters and observations made? This problem was addressed by explaining in great detail the epistemological and ontological stance from which the researcher would work and laying out in great detail the prior experience and knowledge she brought to the study. At any moment, when interpretations were forwarded, these were immediately relativized and complemented with a reminder regarding philosophical stance and background, so as to give the reader the possibility to follow the researcher's reflection and abstraction process and adopt it or not. Other interpretations than the one forwarded as most plausible were also discussed. In the same vein, the complete methodological procedure was carefully documented and detailed out step by step with bountiful procedural examples.

Still, some insecurity remained about how to deal with 'spontaneous conclusions': In the encounters and interviews some interpretations were inevitably shaped and intermediary conclusions came to the foreground. In a morerigorous-than-thou effort to strictly adhere to the methodological prescription (probably typical of scholars that are new to academic research and want to make sure to do it the "right way") such early sense-making moments were at first suppressed as the researcher subordinated herself scrupulously to the imposed coding and fracturing process. Many of these early interpretations were memoed and consulted at later stages but much of it was lost in a sometimes superhuman (one is tempted to say "inhuman") self-effacing disciplinary effort, to go through the motions of the data coding and fracturing procedure. This long and mind-deafening exercise did allow the researcher to eventually come up with plausible concepts, categories and a theory. Yet, the feeling of comfort that the choice of GTM had somehow promised did not install itself. On the contrary, certain questions would not go away, namely if, by opting for apparent epistemic safety through the use of a highly structured procedure to the open field of qualitative inquiry some essential findings had not been sacrificed. What if in an excessive preoccupation for procedure some of the value of the interview data had been displaced from the ends to the means? What would have been the understanding and interpretation of the data at hand had a clear and plain narrative been chosen without the detour via some objectivizing procedural alchemy? By subjecting herself to the unemotional fracturing and coding process the researcher had denied herself the opportunity of simple understanding and interpretation, of direct validity and abandoned the original voice of both the respondents and herself, thus renouncing Habermas' and Lyotard's (1983) privileged or ideal speech communities. Despite intensive memoing doubts remained as to whether the enormous richness of the narrative situations, with their long pauses, their embarrassed laughs, their irritated insistence, their intonations, the various language games, the mess or order on the desks, etc. etc. had really been captured by the radical fragmentation and coding procedures applied.

In the same vein, the validation process whereby the data codification logic and coherence was to be discussed at several levels with a second non-involved academic (member checking) and with the interview partners themselves (respondent checking), posed problems. How could somebody who was not there when the words were spoken, make a reasonable judgment about whether a transcribed interview line was correctly summarized in a particular code? How had that line been spoken, how was it meant: in the first degree, ironically, hesitantly, with determination? What about the fact that the respondent turned away from the interviewer while he spoke these words - or 
smiled meaningfully? And, when asking the respondent, what would be verified? He had said something, which was then transcribed and coded, but what about what he didn't say, and how he didn't say it, and perhaps said later, in other words? The researcher sometimes felt reluctant to forsake the control over the situational understanding and interpretation. It felt wrong to give the very strength of the method out of hand, to delegate it to some methodological proxy. To say the least, these validation sessions provided the researcher and her dialogue partners with some lively and inspiring debates...

Further questions that arose concerned the terminology of GTM, which seemed incoherent. A "theory" that was "grounded" in the data would "emerge" or be "discovered". All these terms implied that there was an objective, underpinning truth laying somewhere in this mountain of data that was gathered. This seemed irritating given that the method had set out to make qualitative inquiry legitimate, to stand and speak up for the validity of phenomenological, interpretative and hermeneutic research. However carefully the research process would be documented, however much the original data and the different abstraction levels would be checked back with members and respondents, the results that emerged would still be constructed. It would be the constructed truth of the researcher and any other researcher going on the same journey was bound to "discover" another truth. And, if so, what was wrong with that? Were these formulae and scientific-sounding, objectivizing terms simply a remnant of a time when qualitative inquiry needed justification in a positivist-dominated environment - or did they stand for an epistemic inconsistency in the method itself?

Regarding generalization, validation and limitations one could ask: how representative of top executive leadership are such journeys as this one? Such constructionist observations of just twenty distinct leaders in ten distinct organizations during one particular window of time in these executives' and organization's life cycles? It could be said that such research strictly concerns ten idiosyncratic companies and their CEOs, and can only be used to understand and/or be applied to those specific companies and situations the researcher was immerged in. But getting very close to executives in specific organizations and moments is a means of making sense, of generalizing about some leadership processes top executives get involved in and shape, and about basic operational and strategic leadership, rather than about all executives or all organizations as such. By observing some unique situations in particular companies and of particular actors, an attempt is made to bring out certain generalizations from these particularities (Watson, 1994, p. 7). In a sense, the uniqueness of the leadership situations and actors studied here is assumed to have a relevance to other unique leadership situations and top executives. It is a matter of, as Yin puts it, "generalizing theoretically, rather than empirically" (Yin, 1984). This is possible because of the "common characteristics that every human being possesses and of the subsequent involvement of all human beings in certain basic social and psychological processes"(Watson, 1994, p. xiii). Underlying individual uniqueness and cultural differences there are processes whereby we all have to make sense of life, engage with others, shape identity, manage feelings and, eventually, come to terms with our own transience. In these basic processes on how we manage our existence there are thus some continuities underlying the many variations observed. Moreover, the general and the particular can also be related because of the "sociological and political-economic continuities, which run through the circumstances of managers generally: the circumstances of advanced capitalism" (Watson, 1994, p. xiv). The executives observed and questioned were all engaged in shaping work activities and furthering purposes that arise within the mechanisms of markets and profit making inherent in German-speaking and increasingly global capitalism. They therefore experience similar pressures, purposes and processes inherent in this particular way of organizing management and act within the same patterns of power, ownership and distribution of wealth and advantage. Empirical generalization, however, is not possible. One cannot say that because a particular executive acted in a particular way in the automotive industry in the year 1998, that other executives, at other times, in other countries, would act the same way when they find themselves in similar circumstances. But if a clear set of analytical principles and theoretical assumptions is applied to these various settings, one can generalize about the basic processual factors that are likely to come into play across these settings.

Such are some issues encountered in this taxing but enriching constructionist journey. The researcher wishes to add that a truly exceptional doctoral advisor had accompanied her, but only once the research strategy had been chosen and most of the data had been generated. Many of the doubts and self-doubts of general and epistemic nature could probably have been alleviated had this partnership and guidance been possible from the onset. On the other hand, had this been so, the researcher would never have read so many volumes on qualitative research nor probably ever felt the need to make this modest contribution to the academic discussion of qualitative research methods. 
Table 1: Summary Of Problems With Current Leadership Research And Suggestions

\begin{tabular}{|c|c|c|}
\hline Problem & Critical question/comment & Suggestion/s \\
\hline $\begin{array}{l}\text { Little progress in } \\
\text { leadership know- } \\
\text { ledge }\end{array}$ & $\begin{array}{l}\text { Despite abundant leadership research we still do not } \\
\text { understand leadership well (Alvesson \& Sve- } \\
\text { ningsson, 2003) }\end{array}$ & $\begin{array}{l}\text { View leadership as process of social interaction; } \\
\text { adopt alternative (interpret.) methods with access to } \\
\text { contextual meaning }\end{array}$ \\
\hline $\begin{array}{l}\text { Extant research } \\
\text { provides little use- } \\
\text { ful to leadership } \\
\text { theorists and prac- } \\
\text { titioners }\end{array}$ & $\begin{array}{l}\text { Extant theories and models are not particularly use- } \\
\text { ful to either theorists (Bryman, 2004; Cummings, } \\
\text { 1981; Meindl, Ehrlich and Dukerich, 1985; Miner, } \\
\text { 1975) or the practitioner confronted with leadership } \\
\text { problems }\end{array}$ & $\begin{array}{l}\text { Adopt alternative (interpret.) methods targeted at un- } \\
\text { derstanding leadership from practitioner's viewpoint. } \\
\text { Work with complexity of 'whole' situations, rather } \\
\text { than units of analysis }\end{array}$ \\
\hline $\begin{array}{l}\text { Dominance of } \\
\text { quant. methods } \\
\text { (ad 'prejudice') }\end{array}$ & $\begin{array}{l}\text { Most leadership research is quantitative in nature: } \\
\text { The self-administered questionnaire is the instrument } \\
\text { of choice (Bryman, 2004). }\end{array}$ & $\begin{array}{l}\text { Adopt alternative research methods, such as narra- } \\
\text { tive interviews, participant observations. }\end{array}$ \\
\hline $\begin{array}{l}\text { 'Qualitative' re- } \\
\text { search, driven by } \\
\text { positivist under- } \\
\text { standing } \\
\text { (ad 'pretense') }\end{array}$ & $\begin{array}{l}\text { Most researchers follow a positivist epistemology, } \\
\text { even when using so-called qualitative methods. Lea- } \\
\text { dership is mostly understood as following a reality } \\
\text { that exists "out there", as an object, separate from the } \\
\text { researcher who observes it }\end{array}$ & $\begin{array}{l}\text { Study qualitative research (QR) methods in detail, } \\
\text { understand the different stances and a adopt a social } \\
\text { constructionist epistemological stance }\end{array}$ \\
\hline $\begin{array}{l}\text { Insufficient expo- } \\
\text { sure to and or sup- } \\
\text { port of students to } \\
\text { use alternative re- } \\
\text { search methods } \\
\text { (ad 'prejudice') }\end{array}$ & $\begin{array}{l}\text { PhD students are mostly trained in positivist research } \\
\text { methods (statistics) and are little exposed to alterna- } \\
\text { tives. At least in continental Europe, students are of- } \\
\text { ten quite alone during conceptual phases. Rigid posi- } \\
\text { tivist procedural guidelines provide greater security } \\
\text { than text books on QR who claim QR to be an 'art' } \\
\text { or a 'craft'. }\end{array}$ & $\begin{array}{l}\text { Introduce alternative methods early in management } \\
\text { studies and discuss their potential; advisor and can- } \\
\text { didate agree on an alternative method relative to } \\
\text { scholar's maturity and experience; Conferences } \\
\text { could provide Research design panels, in addition to } \\
\text { the research results panels. }\end{array}$ \\
\hline $\begin{array}{l}\text { Exigencies of neu- } \\
\text { trality, dispassion } \\
\text { tabula rasa ap- } \\
\text { proach, 'blank } \\
\text { slate' } \\
\text { (ad 'pride') }\end{array}$ & $\begin{array}{l}\text { If the very validity of qualitative inquiry is interpre- } \\
\text { tation and understanding of the social world, why } \\
\text { should the researcher neutralize herself and be re- } \\
\text { duced to the role of an accountant of a mechanistic } \\
\text { procedure? Similarly, if the validity of qualitative in- } \\
\text { quiry is interpretation and understanding, why } \\
\text { should the researcher suppress her knowledge and } \\
\text { experience? }\end{array}$ & $\begin{array}{l}\text { Understand neutrality as ideal, not dogmatism; keep } \\
\text { open mind and willingness to trust in data; disclose } \\
\text { researcher's philosophical stance, prior experience, } \\
\text { etc.; use this experience in the interpretation process; } \\
\text { make the study reflect a point of view, as long as it is } \\
\text { clearly demarcated as such - and interesting and use- } \\
\text { ful }\end{array}$ \\
\hline $\begin{array}{l}\text { Mixed messages } \\
\text { (ad 'prejudice') }\end{array}$ & $\begin{array}{l}\text { Many qualitative methods offer a broad choice of } \\
\text { tools (e.g., realist, impressionist or confessional eth- } \\
\text { nographic tales), encouraging users to adopt any type } \\
\text { of epistemological stance. }\end{array}$ & $\begin{array}{l}\text { Decide for one epistemology and stick with it. Be as } \\
\text { clear and transparent as possible to the reader. }\end{array}$ \\
\hline $\begin{array}{l}\text { Quality criteria, } \\
\text { Validation, gene- } \\
\text { ralization } \\
\text { (ad 'pretense' and } \\
\text { 'prejudice') }\end{array}$ & $\begin{array}{l}\text { There is still considerable pressure to justify qualita- } \\
\text { tive research methods/ results according to inappro- } \\
\text { priate (normative) criteria. Certain normative valida- } \\
\text { tion efforts may well falsify interpretive data instead } \\
\text { of validating it }\end{array}$ & $\begin{array}{l}\text { Use criteria appropriate for QR (e.g. usefulness, re- } \\
\text { levance, coherence, credibility instead of validity, } \\
\text { objectivity, etc.); use member and respondent check- } \\
\text { ing for personal interpellation and interpolation }\end{array}$ \\
\hline $\begin{array}{l}\text { Difficulty to get } \\
\text { qualitative re- } \\
\text { search published } \\
\text { (ad 'prejudice') }\end{array}$ & $\begin{array}{l}\text { It is still difficult to get qualitative research past con- } \\
\text { servative epistemological gatekeepers, be it journal } \\
\text { editors, reviewers or conference committee mem- } \\
\text { bers, etc. }\end{array}$ & $\begin{array}{l}\text { Reviewers should only review manuscripts within } \\
\text { their area of expertise (also research expertise); more } \\
\text { formal appeal procedures should be provided and au- } \\
\text { thors should make use of them }\end{array}$ \\
\hline $\begin{array}{l}\text { Cost/benefit ques- } \\
\text { tion }\end{array}$ & $\begin{array}{l}\text { The end may not justify the enormous means dep- } \\
\text { loyed in some research methods (e.g. GTM). Many } \\
\text { scholars may be deterred by the Herculean effort and } \\
\text { not adopt certain methods more than once in their } \\
\text { lifetime. }\end{array}$ & $\begin{array}{l}\text { Make sure method serves researcher, not vice versa. } \\
\text { Invest less time on coding and more on reflexivity. } \\
\text { QR must have space for interpretation. Document } \\
\text { thoroughly process of 'thinking' and epistemological } \\
\text { stance. QR is time demanding and benefit (in terms } \\
\text { of publications, career) might not be as high as with } \\
\text { quantitative research. However, when the concern is } \\
\text { to generate relevant leadership knowledge and to } \\
\text { progress it seems to be a very relevant way. }\end{array}$ \\
\hline
\end{tabular}




\section{CONCLUSION}

This paper has addressed some epistemological incoherences that we tentatively rooted in rationales of pretense, pride, and prejudice that may pervade among the scientific community regarding the adoption of qualitative research - especially in the leadership field. By reporting two examples of 'genuine' qualitative research we addressed possible research issues and dilemmas that researchers might face when embarking upon a social constructionist research journey. Table 1 summarizes the main issues addressed and our related suggestions how one could deal with them.

We close with some remarks concerning the benefits of qualitative research methods as well as some suggestions on how qualitative research could emancipate itself to overcome the 'hegemony' of positivist research and, hopefully, make leadership and management research richer and possibly more meaningful. The question we try to answer is: What could foster the adoption of an alternative epistemological perspective and lead to more interpretive research?

We believe that a first step toward overcoming current limits would be to envisage that what we consider to be 'good' research and 'true' epistemology, may also just be socially constructed. This 'demystification' would enable a questioning of the status quo and the consideration of alternatives. For this, reflexivity is a decisive means (e.g. Alvesson \& Skøldberg, 2000; Burr, 2003; Cassell \& Symon, 2004; Flick, 1998; Gomm, 2004; Gouldner, 1970; Lincoln \& Guba, 2003; O'Neill, 1972; Patton, 2002; Schön, 1982). Reflexivity does not only encompass the critical review of the research practice's epistemological foundations but also the questioning of knowledge-producing and knowledgesustaining institutions.

Concerning the gate keeping-function of editors and reviewers, we support Bedeian's (2004) suggestions that reviewers should only review manuscripts that are within their area of expertise. In other words, only if they are familiar with qualitative research should they agree to review a qualitative research paper. Furthermore, 'letters to the editor' as well as 'author replies' should be published more often (as it is already done by the American Psychologist or the American Sociological Review). This would provide a forum for authors to further develop and, if necessary, correct misleading or erroneous knowledge claims. Moreover, a formal appeal procedure should be provided for authors who believe that a manuscript has been improperly reviewed. Bedeian (2004, p. 213) cites Simon et al (Simon, Bakanic, \& McPhail, 1986) who report that $13 \%$ of authors asking for reconsideration (in the American Sociological Review) were subsequently published.

With respect to the (inappropriate) choice of quality criteria, we purport that the establishment of criteria against which the quality of research design and results can be judged adequately needs to be further advanced. Some authors have already made a start. For example, Madill et al (Madill, Jordan, \& Shirley, 2000) argue that different criteria are necessary for different epistemological positions. Lincoln and Guba (Lincoln \& Guba, 1986) take up the issue of 'rigor' from various epistemological stances as they go about generating criteria especially suited for constructivist inquiry: "They suggest "credibility as an analog to internal validity, transferability as an analog to external validity, dependability as an analog to reliability, and confirmability as an analog to objectivity"' (cited in Patton, 2002, p. 564). Miles and Huberman propose similar alternative quality criteria to validity and reliability for interpretivist research (Flick, 1998, p. 238; Miles \& Huberman, 1994). Further proposed criteria found in the literature include the research approach's/results' usefulness, relevance, impact and importance; internal coherence, commitment, rigor and transparency of analysis; trustworthiness, authenticity, inter-subjective traceability as well as sensitivity to context (e.g. Burr, 2003; Cassell \& Symon, 2004; Madill, Jordan, \& Shirley, 2000; Patton, 2002; Steinke, 1999). However, as of today none of these criteria have yet received the legitimacy, as have the 'conventional' criteria in the positivist paradigm.

Furthermore, researchers and especially $\mathrm{PhD}$ students need to be exposed to different research methods and epistemological positions. For this, edited volumes and journal articles that present alternative research methods are an important source of legitimacy. They offer the interested researcher the confidence to work according to accepted academic standards and a credible source for citations (Cassell \& Symon, 2004). PhD students are a particularly important target group. Not only will they be particularly involved in actively producing new knowledge, they are also, per- 
haps, more flexible and open for challenging thoughts than researchers who have been practicing the same kind of research for decades. However, the adoption of alternative approaches is endangered by dissertation committees that will not see the value of such approaches (e.g. Patton, 2002), by the time-intensive and complex nature of qualitative research (Conger, 1998) and by journals that might not be willing to publish qualitative findings thus putting the young researchers' careers at a considerable risk. However, besides journals like Organization Studies, Organization and Organization Research Methods who already have a strong commitment to qualitative research methods, even journals with a more conservative reputation such as The Academy of Management Journal have recently acknowledged the value of qualitative research and have stated that "qualitative research is very welcome at AMJ" (Rynes, 2005, p. 13). To implement this statement they have increased the number of board members who are conducting qualitative research and have modified their mission statement. It remains to be seen whether and how quickly the journal and its suppliers will make use of these opportunities and whether the journal's openness to qualitative research also refers to research that adopts an alternative epistemological viewpoint.

Finally, to change the standard of research methods necessitates inter alia the questioning of taken-forgranted epistemological assumptions and an open-mindedness vis-à-vis - as well as tolerance for - unfamiliar research methods. We are aware of the fact that to diverge from familiar patterns of thinking and doing (e.g. research) is a great challenge (that we have experienced ourselves). But still, to promote more inductive, qualitative research is worth trying - not only because it is an intellectually deeply satisfactory reflexive process, but also because the inquiry into some research areas, namely into the area of leadership, cannot be sufficiently given credit to with mechanistic research methods. And the prospects of closely observing unique moments of leadership (as, e. g. in the seminal work of Watson, 1994) and thus advancing the understanding of this the wide and important field through the adoption of interpretive research are gratifying and promising at the same time.

\section{REFERENCES}

1. Alvesson, M., \& Skøldberg, K. (2000). Reflexive Methodology: New Vistas for Qualitative Research. London: Sage.

2. Alvesson, M., \& Sveningsson, S. (2003). The Great Disappearing Act: Difficulties in Doing 'Leadership'. The Leadership Quarterly, 14, 359-381.

3. Bass, B. M. (1990). Handbook of Leadership: Theory, Research and Managerial Applications. New York: Free Press.

4. Bedeian, A. G. (2004). Peer Review and The Social Construction of Knowledge in the Management Discipline. Academy of Management Learning and Education, 3, 198-216.

5. Berger, P., \& Luckmann, T. (1966). The Social Construction of Reality. A Treatise in the Sociology of Knowledge. London: Penguin.

6. $\quad$ Blake, R. R., \& Mouton, J. S. (1964). The Managerial Grid: Gulf Publishing.

7. Blanchard, K. H., \& Johnson, S. (2000). The One Minute Manager. New York: HarperCollins.

8. Boos, F., \& Heitger, B. (1996). Kunst oder Technik? Der Projektmanager als sozialer Architekt. In H. Balck (Ed.), Networking und Projektorientierung - Gestalten des Wandels in Unternehmen und Märkten. Berlin: Springer.

9. Bryman, A. (1984). The Debate About Quantitative and Qualitative Research: A Question of Method or Epistemology? British Journal of Sociology, 35, 75-92.

10. Bryman, A. (2004). Qualitative Research on Leadership: A Critical but Appreciative Review. The Leadership Quarterly, 15, 729-769.

11. Bryman, A., Bresnen, M., Beardsworth, A., \& Keil, T. (1988). Qualitative Research and the Study of Leadership. Human Relations, 41, 13-30.

12. Burns, J. M. (1978). Leadership. New York: Harper \& Row.

13. Burr, V. (2003). Social Constructionism (2nd ed.). London: Routledge.

14. Carlyle, T., Goldberg, M. K., Brattin, J. J., \& Engel, M. (1993). On Heroes, Hero-Worship \& the Heroic in History: Unviersity of California Press.

15. Cassell, C., \& Symon, G. (2004). Essential Guide to Qualitative Methods in Organizational Research. London: Sage.

16. Charmaz, K. (2000). Grounded Theory: Objectivist and Constructivist Methods. In N. K. Denzin \& Y. S. Lincoln (Eds.), Handbook of Qualitative Research (2 ed., pp. 509). Thousand Oaks: Sage.

17. Charmaz, K. (2006). Constructing Grounded Theory - A Practical Guide Through Qualitative Analysis. London: Sage. 
18. Charmaz, K., \& Mitchell, R. (1996). The Myth of Silent Authorship. Symbolic Interaction, 19, $285-302$.

19. Clark, K. E., \& Clark, M. B. (1994). Choosing to Lead: A Center for Creative Leadership Book. Charlotte: Leadership Press.

20. Clarkson, P. (1989). Gestalt Counselling in Action. London: Sage.

21. Cohen, L., \& Manion, L. (1989). Research Methods in Education. London: Croom Helm.

22. Conger, J. A. (1998). Qualitative Research as the Cornerstone Methodology for Understanding Leadership. The Leadership Quarterly, 9, 107-121.

23. Covey, S. R. (1990). The Seven Habits of Highly Effective People - Restoring the Character Ethic. Toronto: Simon \& Schuster.

24. Covey, S. R., Merrill, A. R., \& Merrill, R. (1994). First Things First. Toronto: Simon \& Schuster.

25. Crotty, M. (1998). The Foundations of Social Research. London: Sage.

26. Cummings, L. L. (1981). Organizational Behavior in the 1980s. Decision Sciences, 12, 365-377.

27. Czarniawska, B. (2004). Narratives in Social Science Research. London: Sage.

28. Dachler, H. P. (1988). Constraints on the Emergence of New Vistas in Leadership and Management Research: An Epistemological Overview. In J. G. Hunt, B. R. Baliga, H. P. Dachler \& C. A. Schriesheim (Eds.), Emerging Leadership Vistas (pp. 261-285). Lexington: Lexington Books.

29. Dachler, H. P. (1997). Does the Distinction Between Qualitative and Quantitative Methods make Sense? Book Review Essay on Catherine Cassell and Gilian Symon (eds.): Qualitative Methods in Organizational Research: A Practical Guide. Organization Studies, 18(4), 709-724.

30. Dachler, H. P., \& Hosking, D. M. (1995). The Primacy of Relations in Socially Constructing organizational Realities. In D. M. Hosking, H. P. Dachler \& K. J. Gergen (Eds.), Management and Organization: Relational Alternatives to Individualism (pp. 1-28). Aldershot: Avebury.

31. Denzin, N. K., \& Lincoln, Y. S. (2003). Introduction. The Discipline and Practice of Qualitative Research. In N. K. Denzin \& Y. S. Lincoln (Eds.), The Landscape of Qualitative Research. Theories and Issues (pp. 1-45). Thousand Oaks: Sage.

32. Easterby-Smith, M., Thorpe, R., \& Lowe, A. (2002). Management Research - An Introduction (2nd, 2003 ed.), London: Sage.

33. Eisenhardt, K. M. (1989). Building Theory from Case Study Research. Academy of Management Review, 14 (4), 532-550.

34. Eisner, E. (1993). Objectivity in Educational Research. In M. Hammersley (Ed.), Educational Research: Current Issues (pp. 49-56). London: Chapman.

35. Fendt, J. (2005). The CEO in Post-Merger Situations: An Emerging Theory on the Management of Multiple Realities. Delft: Eburon.

36. Fish, S. (1994). There's No Such Thing as Free Speech. Oxford: Oxford University Press.

37. Flick, U. (1998). An Introduction to Qualitative Research. London Sage.

38. Gadamer, H.-G. (1972). Wahrheit und Methode. Grundzüge einer philosophischen Hermeneutik (3rd ed.). Tübingen.

39. Gergen, K. J. (1994). Realities and Relationship: Soundings in Social Construction. Cambridge: Harvard University Press.

40. Gergen, K. J. (1995). Relational Theory and the Discourses of Power. In D. M. Hosking, H. P. Dachler \& K. J. Gergen (Eds.), Management and Organization: Relational Alternatives to Individualism. Avebury: Aldershot.

41. Glaser, B. G. (1978). Theoretical Sensitivity: Advances in the Methodology of Grounded Theory. Mill Valley: Sociological Press.

42. Glaser, B. G. (1992). Emergence versus Forcing: Basics of Grounded Theory Analysis. Mill Valley: Sociology Press.

43. Glaser, B. G., \& Strauss, A. L. (1967). The Discovery of Grounded Theory: Strategies for Qualitative Research. New York: De Gruyter.

44. Gomm, R. (2004). Social Research Methodology - A Critical Introduction. New York: Palgrave Macmillan.

45. Goulding, C. (2002). Grounded Theory - A Practical Guide for Management, Business and Market Researchers. London: Sage.

46. Gouldner, A. W. (1970). The Coming Crisis of Western Sociology. New York: Basic Books.

47. Hersey, P., \& Blanchard, K. H. (1969). Life Cycle Theory of Leadership. Training \& Development Journal, 23 , 26-42.

48. Herzberg, F., Mausmer, B., \& Snyderman, B. B. (1959). The Motivation to Work. New York: Wiley \& Sons.

49. Heylighen, F., \& Joslyn, C. (2001). Cybernetics and Second-Order Cybernetics. In R. A. Meyers (Ed.), Encyclopedia of Physical Science and Technology (pp. 155-187). New York: Academic Press. 
50. $\quad$ Kanter, R. M. (1989). The New Managerial Work. Harvard Business Review, 67(6), 85.

51. King, N. (2004). Using Interviews in Qualitative Research. In C. Cassell \& G. Symon (Eds.), Essential Guide to Qualitative Methods in Organizational Research. London: Sage.

52. Kirk, J., \& Miller, M. L. (1986). Reliability and Validity in Qualitative Research. London Sage.

53. Kvale, S. (1995). Validierung: Von der Beobachtung zu Kommunikation und Handeln. In U. Flick, E. von Kardorff, H. Keupp, L. von Rosenstiel \& S. Wolff (Eds.), Handbuch qualitativer Sozialforschung. Grundlagen, Konzepte, Methoden und Anwendungen (pp. 427-431). Weinheim: Psychologie Verlags Union.

54. Lawler, E. E. (1987). Transformations From Control to Involvement. In R. H. Killman \& T. J. Covin (Eds.), Corporate Transformation. San Francisco: Jossey-Bas.

55. Lincoln, Y. S., \& Guba, E. G. (1985). Naturalistic Inquiry. Beverly Hills: Sage.

56. Lincoln, Y. S., \& Guba, E. G. (1986). But is it Rigorous? Trustworthiness and Authenticity in Naturalistic Evaluation. In D. D. Williams (Ed.), Naturalistic Evaluation. New Directions for Program Evaluation (pp. 73-84). San Francisco: Jossey-Bass.

57. Lincoln, Y. S., \& Guba, E. G. (2003). Paradigmatic Controversies, Contradictions and Emerging Confluences. In N. K. Denzin \& Y. S. Lincoln (Eds.), The Landscape of Qualitative Research. Theories and Issues (pp. 253-291). Thousand Oaks: Sage.

58. Locke, K. (2001). Grounded Theory in Management Research. London: Sage.

59. Lord, R. G., \& Maher, K. J. (1991). Leadership and Information Processing: Linking Perceptions and Performance (1993 (Paperback) ed.). London: Routledge.

60. Luhmann, N. (1994). The World Society as a Social System. International Journal of General Systems, 8(2), 131162.

61. Lyotard, J.-F. (1983). Le Différend. Paris: Minuit.

62. Machiavelli, N. (1610). Il Principe (1995 ed.): Einaudi Tascabili.

63. Madill, A., Jordan, A., \& Shirley, C. (2000). Objectivity and Reliability in Qualitative Analysis: Realist, Contextualist and Radical Constructionist Epistemologies. British Journal of Psychology, 91, 1-20.

64. Maslow, A. H. (1954). Motivation and Personality. New York: Harper \& Row.

65. Maturana, H., \& Varela, F. (1992). The Tree of Knowledge. Boston: Shambhals.

66. Mayo, G. E. (1924-27). Hawthorne Experiments.

67. McClintock, C. C., Brannon, D., \& Maynard-Moody, S. (1979). Applying the Logic of Sample Surveys to Qualitative Case Studies: The Case Cluster Method. Administrative Science Quarterly, 24(4), 612-629.

68. McDonald, S., Daniels, K., \& Harris, C. (2004). Cognitive Mapping in Organizational Research. In C. Cassell \& G. Symon (Eds.), Essential Guide to Qualitative Methods in Organizational Research (pp. 73-85). London: Sage.

69. Meindl, J. R., Ehrlich, S. B., \& Dukerich, J. M. (1985). The Romance of Leadership. Administrative Science Quarterly, 30, 78-102.

70. Miles, M. B., \& Huberman, A. M. (1994). Qualitative Data Analysis (2nd ed.). Thousand Oaks: Sage.

71. Nietzsche, F. (1967). Sämtliche Werke (Kritische Studienausgabe 1967-1977 ed.). New York: De Gruyter.

72. O'Neill, J. (1972). Sociology as a Skin Trade: Essays Towards a Reflexive Sociology. New York: Harper \& Row.

73. Patton, M. Q. (2002). Qualitative Research and Evaluation Methods (3rd ed.). Thousand Oaks: Sage.

74. Peräkylä, A. (2004). Reliability and Validity in Research Based on Naturally Occurring Social Interaction. In D. Silverman (Ed.), Qualitative Research - Theory Method and Practice (2nd ed.). London: Sage.

75. Peters, T. J. (1992). Liberation Management-Necessary Disorganization for the Nanosecond Nineties. Toronto: Random House.

76. Peterson, I. (1988). The Mathematical Tourist:Snapshots in Modern Mathematics. New York: Freeman.

77. Remenyi, D., Williams, B., Money, A., \& Swartz, E. (1998). Doing Research in Business and Management. London: Sage.

78. Rüegg-Stürm, J., \& Gritsch, L. (2001). Ungewissheit und Stabilität in Veränderungsprozessen - Zur Bedeutung von Ritualen in tiefgreifenden Veränderungsprozessen von Unternehmen (Discussion Paper No. 42): University of St. Gall.

79. Ryle, G. (1949). The Concept of Mind. New York: Barnes and Noble.

80. Rynes, S. L. (2005). From The Editors: Taking Stock and Looking Ahead. Academy of Management Journal, 48, 9-15.

81. Schön, D. A. (1982). The Reflective Practitioner: How Professionals Think in Action. New York: Basic Books.

82. Sherman, B. (1988). Hermeneutics in Law. Modern Law Review, 51, 395-409.

83. Silverman, D. (2001). Interpreting Qualitative Data: Methods for Analysing Talk, Text and Interaction (2nd ed.). London: Sage. 
84. Silverman, D. (2004). Who Cares About 'Experience'? Missing Issues in Qualitative Research. In D. Silverman (Ed.), Qualitative Research: Theory, Method and Practice. London: Sage.

85. Simon, R. J., Bakanic, V., \& McPhail, C. (1986). Who Complains to Journal Editors and What Happens? Sociological Inquiry, 56, 259-271.

86. Smircich, L. (1983). Studying Organizations as Cultures. In G. Morgan (Ed.), Beyond Method. Strategies for Social Research (pp. 160-172). Beverly Hills: Sage.

87. Steinke, I. (1999). Kriterien qualitativer Forschung: Ansätze zur Bewertung qualitativ-empirischer Sozialforschung. München: Weinheim.

88. Strauss, A. L. (1987). Qualitative Analysis for Social Scientists. Cambridge: Cambridge University Press.

89. Strauss, A. L., \& Corbin, J. (1998). Basics of Qualitative Research: Techniques and Procedures for Developing Grounded Theory (2nd ed.). Thousand Oaks: Sage.

90. Van Maanen, J. (1988). Tales of the Field: On Writing Ethnography. Chicago: University of Chicago Press.

91. von Foerster, H. (1995). Ethics and Second Order Cybernetics. Stanford Humanities Review, 4(2).

92. Watson, T. J. (1994). In Search of Management (2001 ed.). London: Thomson Learning.

93. Watzlawick, P. (1995). Wie wirklich ist die Wirklichkeit: Wahn, Täuschung, Verstehen. München: Piper.

94. Watzlawick, P. (1997). Die erfundene Wirklichkeit: Wie wissen wir, was wir zu wissen glauben? München: Piper.

95. Watzlawick, P., \& Kreuzer, F. (2000). Die Unsicherheit unserer Wirklichkeit. Ein Gespräch über den Konstruktivismus. München: Piper.

96. Weber, M. (1947). The Theory of Social and Economic Organization. New York: Macmillan.

97. Yin, R. K. (1982). Studying the Implementation of Public Programs. In W. Williams (Ed.), Studying Implementation: Methodological and Administrative Issues (pp. 36-72). Chatham: Chatham House.

98. Yin, R. K. (1984). Case Study Research. Beverly Hills: Sage.

99. Zimmer, B. (2001). Practicing What we Teach in Teaching Systems Practice: The Action Learning Cycle. Systemic Practice and Action Research, 14(6).

\section{END NOTES}

${ }^{\mathrm{i}}$ Even though the focus in this paper is on leadership research, our arguments may also apply to other areas of management and organizational research, where meaning making of social interaction is sought.

ii Some scholars distinguish between constructionism and constructivism. The terminology is however far from consistent (c.f. Crotty (1998) and Ryle (1949) for a discussion on the misapplication of epistemological terms). Gergen (1994) and Burr (2003) speak of social constructionists and psychological constructivists. Crotty proposes that constructivism be used for epistemological considerations focusing on the: "...meaning-making activity of the individual mind", and constructionism be used where the focus includes the "...collective generation (and transmission) of meaning" (1998, p. 58). In coherence with this, the terms "constructionist' and 'social constructionism' are used in this study to accentuate the focus on the social phenomena of leadership.

iii Gergen (1995) speaks in this context of 'presumption of human relatedness'.

iv Boos and Heitger (1996) formulate this as follows: "What is real is already a decision".

${ }^{v}$ Cybernetics (e.g. Heylighen \& Joslyn, 2001; von Foerster, 1995; Zimmer, 2001) is the discipline that studies the abstract principles of organisation in complex systems. Cybernetic reasoning is inherently transdisciplinary and can be applied to understand, model and design systems of any kind: physical, technical, biological, ecological, social, psychological or any combination thereof. Whilst cybernetics is interested in the similarities between living systems and machines, Second-order cybernetics emphasises autonomy, self-organisation and cognition and especially the role of the observer in modelling a system. The observer, inseparable from the system, is also a cybernetic system trying to construct a model of another cybernetic system. To understand this process, a 'cybernetics of cybernetics' was needed: second-order cybernetics.

${ }^{v i}$ cf. e.g. the large body of work by the Chilean biologists Maturana and Varela (1992) usually referred to collectively as 'autopoietic theory'. At the heart of their work lies the description of a process called "autopoiesis", which is concerned with the dynamics of living systems. Rather than enumerating features of living systems in order to define 'life', Maturana and Varela wanted to capture the invariant feature of living systems around which natural selection operates. His goal was to retain the autonomy of living systems as a central feature, without recourse to referential concepts such as 'function' or 'purpose'. Since this body of knowledge contains significant new perspectives on such concepts as behaviour and observation, it is easy to understand why this theory appealed to many other academic disciplines. 